\author{
AMIRA BAR SHALOM* \\ Higher Studies of Israel
}

\title{
THE HANDINHAND SCHOOL: DEALING WITH ADVERSITY WITHIN A MULTICULTURAL CONTEXT
}

\begin{abstract}
Aвstract. Bar Shalom Amira, The Handinhand School: Dealing with Adversity within a Multicultural Context [Szkoła Handinhand: radzenie sobie z trudnościami w kontekście wielokulturowym]. Studia Edukacyjne nr 48, 2018, Poznań 2018, pp. 367-375. Adam Mickiewicz University Press. ISSN 1233-6688. DOI: $10.14746 /$ se.2018.48.24
\end{abstract}

The Hand in Hand bilingual school in Jerusalem operates against the broader background of the Arab-Israeli conflict and the unequal relations between Jewish and Arab citizens in the State of Israel. Drawing on multicultural educational models, the School seeks to ensure that all groups are visible and respected and to develop a curriculum that reflects the culture of all the students and their families. Against the dominant model of segregated education in Israel, the School creates intercultural space. In recent years, the School has been the target of several attacks. The article describes the work of the author, a counselor at the School, in responding to these attacks and in enhancing the resilience of the School community. Structured staff meetings enabled the educators to express themselves, support each other, and receive tools for coping in multicultural classrooms in a conflicted society.

Key words: multicultural education, bilingual education, Arab citizens of Israel, teacher counseling

\section{Inequality between Arabs and Jews}

The Hand in Hand bilingual school in Jerusalem operates in the context of the unequal relations between Arabs and Jews. Israel has become an increasingly inegalitarian country in recent years, ${ }^{1}$ and Arab citizens, who constitute approximately one-fifth of the population, are the poorest community in the country.

Although Arab citizens have gained considerable civil rights over recent decades, gaps and discrimination remain in almost every area of life. The

* The author is a counselor at the Hand in Hand bilingual school in Jerusalem.

${ }^{1}$ D. Ben-David, H. Bleikh, Poverty and Inequality Over Time: In Israel and in the OECD, Jerusalem 2013. 
Arab education system receives significantly lower budgets than the Jewish system, ${ }^{2}$ and the proportion of Arabs entering higher education is half that among Jews. ${ }^{3}$ Arab students perform less well in the university admission tests, and Arab graduates are much less likely than their Jewish peers to find suitable positions in their field. Similar gaps can be seen in other fields, including health, infrastructures, and employment.

\section{Multicultural Programs in Conflicted Areas}

Multiculturalism encourages understanding and cooperation between people from different cultures. ${ }^{4}$ Exponents of multicultural education emphasize the need to provide a high-quality education while enabling all groups to feel that they are visible and respected. Taylor (1992) emphasized that multicultural education should provide the sense of recognition that some individuals and groups lack. ${ }^{5}$

Multicultural education has received encouragement from academic institutions, particularly in the United States and Europe. ${ }^{6}$ Multiculturalism is a dynamic and changing concept, in part due to the complex discourse of post-colonialist critique. ${ }^{7}$ However, there is a general consensus that it seeks to represent voices and communities that have been silenced over many years. This approach entered schools as critical educators recognized that it was not sufficient, for example, simply to place African-American and white students together. It is also vital to develop a curriculum that reflects the culture of excluded groups. A "good school" instills a sense of pride in the students regarding their own culture alongside an appreciation of other cultures. ${ }^{8}$

The School examined in this study is both multicultural and bilingual. There is a significant distinction between bilingual schools in which the children study both language in monolingual groups and ones where students from the majority and minority groups study together. The professional lite-

${ }^{2}$ D. Golan-Agnon, Why are Arab Students Discriminated Against? [in:] Inequality in Education, Ed. D. Golan-Agnon, Tel Aviv 2004, p. 83-90. 2016.

A. Beeri-Sulitzeanu, D. Muhammad, Information File - Arab Society in Israel, Jerusalem

${ }^{4}$ J.A. Banks, A. Cherry, B. McGee, Multicultural Education: Issues and Perspectives, Hoboken, New York 2004.

${ }^{5}$ Ch. Taylor, Multiculturalism and the Politics of Recognition, Ed. A. Gutmann, Princeton New York 1992.

${ }^{6}$ D.M. Gollnick, P.C. Chinn, Multicultural Education in a Pluralistic Society. Front Cover. D.M. Gollnick, P.C. Chinn, Toronto 1994.

7 J. Rex, G. Singh, Pluralism and Multiculturalism in Colonial Society - 106 Thematic Introduction, International Journal on Multicultural Societies, 2003, 5, 2.

${ }^{8}$ R. Sabar, Y. Gur, Contact Lenses: Intercultural Mediation in a Youth Village with a Large Proportion of Ethiopian Students, Mifgash L'avoda Hinuchit Sotzialit, 2001, 15. 
rature appears to show a preference for the latter model, as Torres-Guzman (2002) notes regarding the example of Florida. ${ }^{9}$ In her example, and in our own context, we see an insistence on ensuring that both languages are used as mediums of instruction. English is the dominant language in the United States, just as Hebrew is in Israel. However, bilingual learning may enhance the students' awareness that they share a common arena in which they seek to develop their intellectual, social, and linguistic skills. ${ }^{10}$

We can observe in the West a pendulum that swings between a respectful and inclusive approach to the "other" and a suspicious or even hostile approach. In Israel, too, both these trends are very much in evidence. Prime Minister Netanyahu courted Jewish votes by declaring on election day that "the Arabs are heading to the polling booths in droves." However, the current right-wing education minister supports the School.

Multicultural education must have a strong institutional support. A study sponsored by the National College for School Leadership (NCSL) in Great Britain found that school principals who were personally committed to social justice adhered to multicultural educational approaches and searched for strategies to facilitate the academic progress of all students. ${ }^{11}$

\section{Bilingual Schools in Israel and the Hand in Hand School in Jerusalem}

During the nation-building phase, Israel established separate education systems for Arabs and Jews, with a further distinction within the Jewish population between religious (Orthodox) and general streams. Both ultra-Orthodox Jews and Arabs studied in completely separate education systems. During the early period, the general education system adopted a "melting pot" ideology and sought to inculcate a monolithic Jewish-Zionist identity. ${ }^{12}$ Jewish immigrant students were encouraged to assimilate into the majority culture, ${ }^{13}$ indeed, this culture was often the only one presented to the children. ${ }^{14}$

${ }^{9}$ M.E. Torres-Guzmán, Dual Language Programs: Key Features and Results, Directions in Language and Education, Spring 2002, 14.

${ }_{10}$ R.D. Freeman, Dual Language Planning at Oyster Bilingual School: It's Much More than Language, TESOL Quarterly, 1996, 30(3).

11 A. Walker, Priorities, Strategies and Challenges: Proactive Leadership in Multi-Ethnic Schools, National College for School Leadership, 2004, http://citeseerx.ist.psu.edu/viewdoc/download?doi=10.1.1.520.4816andrep=rep1andtype=pdf [retrieved: 29 April 2017].

${ }_{12}$ D. Bar-On, The Others Within Us: Constructing Jewish-Israeli Identity, Cambridge 1999.

${ }^{13}$ R. Sabar, Y. Gur, Contact Lenses.

${ }^{14}$ N. Peled-Elhanan, When the Other is Unseen, Unheard, and Unknown: From Teaching as Socialization and Culture to Teaching as Access and Inclusion, Bamikhlala, 2007, 1. 
Over the years, and especially in the last two decades, new schools were established that adopted the ethos of ideological pluralism, such as institutions catering for students from the Ethiopian community ${ }^{15}$ and the Former Soviet Union. ${ }^{16}$ Other schools bring together religious and secular Jewish students or teach both Arabs and Jews on the basis of an egalitarian curriculum, as at the Neve Shalom School, which is a bilingual school. ${ }^{17}$

The professional literature relating to bilingual schools in Israel comprises mainly the studies relatingto Neve Shalom, ${ }^{18}$ as well as studies examining the Hand-in-Hand Association. ${ }^{19}$ The students at the Hand-in-Hand schools do not live in a consciously egalitarian and mixed community such as Neve Shalom. While Jerusalem is a mixed city, its various neighborhoods that have a clear ethnic identity, so that the School has particular symbolic and practical importance as an intercultural space. It is important to note that the majority of parents who send their children to bilingual schools, whether Jews or Arabs, belong to the cultural elite. Bekerman and Horenczyk (2004) added that while the Jewish parents prioritized ideological considerations, ${ }^{20}$ Arab parents focused on their desire to remove their children from the poor Arab education system over such concerns. Bekerman recently published a book summarizing the comprehensive studies on the bilingual schools in the Hand-in-Hand network between 1999 and 2013 (most of the research being conducted prior to 2013).

\section{Dealing with Adversity}

In recent years, the School has been the target of several attacks. The researcher, who serves in a senior position as School Counselor within the School, helped the educational staff and the management of the school to cope with these new conditions of external adversity. It is also important to note that the present paper was authored by someone who herself works as part of the

${ }^{15}$ R. Sabar, Y. Gur, Contact Lenses.

16 S. Shammai, Z. Elitub, T. Horowitz, The Story of an Educational Revolution, Jerusalem 2010.

17 Y. Bar Shalom, Educating Israel: Educational Entrepreneurship in Israel's Multicultural Society, New York 2006.

${ }_{18}$ G. Feuverger, Oasis of Dreams: Teaching and Learning Peace in a Jewish-Palestinian Village in Israel, New York 2001; Y. Bar Shalom, Educating Israel; A. Lieblich, Against All Odds: The Story of a Binational Village, Tel Aviv 2015.

19 Z. Bekerman, G. Horenczyk, Arab-Jewish Bilingual Coeducation in Israel: A Long-term Approach to Inter-group Conflict Resolution, Journal of Social Issues, 2004, 60(2); Z. Bekerman, On their Way Somewhere: Integrated Bilingual Palestinian Jewish Education in Israel, [in:] Learning from Alternative Educations: Priorities for Promoting Democracy and Holistic Human Growth in Contemporary Education Systems, Eds. P. Woods, G. Woods, Basingstoke 2009.

${ }^{20}$ Z. Bekerman, G. Horenczyk, Arab-Jewish Bilingual Coeducation in Israel. 
inner staff of the School. In this respect, the author identifies with the stream of Feminist researchers who advocate a participatory model. ${ }^{21}$ Thus the present study constitutes an example of "practitioner research," in which the researcher examines his/her own field of work..$^{22}$ This type of research may be particularly useful for researchers in social and educational fields.

\section{Hate Crimes}

Two examples illustrate how the practitioners at the school operate in the face of adversity.The first example concerns a minor event (graffiti); the second was a very serious incident when members of a right-wing Jewish organization attempted to torch the school, damaging one classroom.

Hate crimes are usually committed against ethnic or religious minorities and may include physical and verbal violence (including graffiti), vandalism, incitement to racism, and even murder. While awareness of hate crime has risen sharply, this has not led to the eradication of the phenomenon. ${ }^{23}$

Hate crimes do not only effect their direct target, but also all the members of the minority group to which the victim belongs. Various studies have shown that the victims of these crimes are particularly prone to post-traumatic stress disorder (PTSD), anxiety, and depression. ${ }^{24}$ Important educational actions in confronting hate crimes include outreach to encourage tolerance and acceptance of the other from an early age. Challenging stereotypes, changing public policy, and enhancing penalization are among the other means that can help reduce this phenomenon.

In February2014, slogans were daubed on the perimeter walls of the School, including the statements "Death to Arabs" and "Kahane was right" (Kahane was an extreme right-wing Jewish leader who is still a focus for racistand anti-Arab sentiments).

After the incident, students and educators gathered in their classes to provide the children with space to share and express their emotions. The children decided that they wanted to hang posters outside the school supporting

${ }^{21}$ S. Reinharz, Feminist Distrust: Problems of Content and Context in Sociological Research, [in:] The Self in Social Inquiry, Eds. D. Berg, K. Smith, Beverly Hills 1985; M.L. Devault, Talking Back to Sociology: Distinctive Contributions of Feminist Methodology, Annual Review of Sociology, 1996, 22; P. Cotterill, Interviewing Women: Issues of Friendship, Vulnerability, and Power, Women's Studies International Forum, 1992, 15(5/6).

${ }^{22}$ H. Kara, Research and evaluation for busy practitioners: a time-saving guide, Bristol 2012.

${ }^{23}$ J. Bell, Policing Hatred, New York 2002.

${ }^{24}$ W. Abu-Ras, S.H. Abu-Bader, Risk Factors for Depression and Posttraumatic Stress Disorder (PTSD): The Case of Arab and Muslim Americans Post-9/11, Journal of Immigrant and Refugee Studies, 2009, 7, 4 . 
coexistence and dialogue and opposing racism. Inthe second stage, all the teachers and educators at the School met in the staffroom with the principals and the School supervisor. The participants in the meeting discussed ways to let the children express themselves and considered how the School should respond. Later the same week, the students held various activities against racism, including sending letters opposing racism and hatred to all the Members of Knesset.

On the day of the incident, I arrived at the School in the morning for a counseling session with a student. At recess I opened the staffroom door and found that the School inspector and the principals were discussing the incident, of which I had previously been unaware.

After the meeting ended, I shared my concern with the Jewish principalthat I had been unaware of the incident. She apologized and acknowledged that I should certainly be involved and present. Since I began to work at the School, I had helped to organize interventions in the form of discussion circles and circles to share emotions. After the atmosphere at the School began to calm down, I initiated discussion circles every two weeks providing an opportunity for the educators to express themselves in a safe environment, support each other, and receive tools for coping in multicultural classrooms.

These sessions were one of the elements that strengthened the School staff as they coped with a further incident later in 2014 when one of the classrooms at the School was torched in a nighttime attack (no injuries resulted). Again, the School used the mechanism of discussion circles to provide support for parents, students, and staff. The staff and the Association of Hand in Hand Schools recruited broad political and public support for the School and condemnation of the attack.

Despite the serious nature of this incident, the researcher noted that the School was much better prepared for this second attack thanks to the profound work that had been undertaken, including the supervision sessions.

\section{Reflection on Supervision Sessions}

All the sessions were held in the counselor's room at a regular time and day. All the participants came to some sessions, while in other cases one or two were missing, which made it harder to run the workshop. The educators cooperated throughout the sessions and expressed a desire to come to meetings, despite their busy work schedules.

The researcher sought to promote a degree of cohesion among the educators in order to create a group that can provide mutual support when needed, 
whether on the emotional level or in the field of didactics and study, or in responding to stress following incidents such as the graffiti and torching events described above. A cohesive group creates its own gravity that encourages the members to remain active. The members of such a group feel warmth, comfort, and a sense of belonging. The group is important to them and they feel that it provides them with appreciation and support. As Rosenwasser (1997) notes, mutual dependency is one of the hallmarks of a group. Some of the exercises we ran required cooperation and mutual dependency among the members, encouraging the educators to cope with a common challenge. ${ }^{25}$

The group work enabled the researcher to examine her own position within the group. She discovered that she sometimes played a prominent role in the group and felt that she must assume responsibility, while at other times she listened to the group and letting it flow at its own pace. At some points the group underwent familiar processes of consolidation, despite the fact that some of the educators had already known each other for a long time. ${ }^{26}$ The researcher also noticed that the group underwent the stages of consolidation described by Peck, from a "false community" through storm, silence, and consolidation to a "true community (Peck, 1987).

In conclusion, group cohesion, based on norms facilitating openness and relations of trust, emerge in a group structure that allows the individuals to examine new forms of behavior in a protected and safe space. From a formalistic perspective, a group is a structure in which two or more people create relations and interaction (Forsyth, 2006). Proper facilitation, it seems, can enable a group of strangers to become a cohesive group allowing its members to develop and grow, and enabling the group itself to become a true community (Peck, 1992).

As Rosenwasser noted (1997), the facilitator intervenes according to the development stages of the group, with the goal of empowering individuals and the group as a whole. ${ }^{27}$ The facilitator plays a proactive role, and accordingly the group work described here was an interesting, challenging, and enjoyable experience for the researcher.

It is important to emphasize that the group work described here was prepared following an instance of hate crime. During the work process, however, we found that as well as enhancing group cohesion in response to situations of stress and pressure, the group work also improved the work of the staff, the intercultural contact, and open dialogue between the different members of the group.

\footnotetext{
${ }^{25}$ N. Rosenwasser (Ed.), Group Counseling, Jerusalem 1997.

${ }^{26}$ Cf. B.W. Tuckman, Developmental Sequence in Small Groups, Psychological Bulletin, 1965, 63.

${ }^{27}$ N. Rosenwasser (Ed.), Group Counseling.
} 


\section{Conclusion}

This article has attempted to describe the work at a unique school that brings together Jewish and Arab students in conditions of equality that are not found in broader Israeli society. The second part of the article described the work of an educational counselor coping with questions about her position following a traumatic incident. As we saw, the counselor chose to see the initial crisis as an opportunity for growth. This led to the writing of an intervention plan allowing Jewish and Arab teachers to share their feelings through a joint process that focused on sensitive issues. The counselor worked alone as a facilitator in this process, but is pleased to report that the school has recently recruited a second counselor, who comes from Arab society, thereby ensuring that the counseling work at the School is egalitarian in terms of cultural representation. While the School may be a drop in the ocean, any meaningful social change begins with modest initiatives that later expand and develop.

\section{BIBLIOGRAPHY}

Abu-Ras W., Abu-Bader S.H., Risk Factors for Depression and Posttraumatic Stress Disorder (PTSD): The Case of Arab and Muslim Americans Post-9/11, Journal of Immigrant and Refugee Studies, 2009, 7, 4.

Banks J.A., Cherry A., McGee B., Multicultural Education: Issues and Perspectives, Hoboken, Wiley, New York 2004.

Bar Shalom Y., Educating Israel: Educational Entrepreneurship in Israel's Multicultural Society, Palgrave Macmillan, New York 2006.

Bar-On D., The Others Within Us: Constructing Jewish-Israeli Identity, Cambridge University Press, Cambridge 1999.

Beeri-Sulitzeanu A., Muhammad D., Information File - Arab Society in Israel, Abraham Fund Publications, Jerusalem 2016 (in Hebrew).

Bekerman Z., On their Way Somewhere: Integrated Bilingual Palestinian Jewish Education in Israel, [in:] Learning from Alternative Educations: Priorities for Promoting Democracy and Holistic Human Growth in Contemporary Education Systems, Eds. P. Woods, G. Woods, Palgrave, Basingstoke 2009.

Bekerman Z., Horenczyk G., Arab-Jewish Bilingual Coeducation in Israel: A Long-term Approach to Inter-group Conflict Resolution, Journal of Social Issues, 2004, 60(2).

Bell J., Policing Hatred, New York University Press, New York 2002.

Ben-David D., Bleikh H., Poverty and Inequality Over Time: In Israel and in the OECD, Taub Center for Social Policy Studies in Israel, Jerusalem 2013.

Cotterill P., Interviewing Women: Issues of Friendship, Vulnerability, and Power, Women's Studies International Forum, 1992, 15(5/6).

Devault M.L., Talking Back to Sociology: Distinctive Contributions of Feminist Methodology, Annual Review of Sociology, 1996, 22. 
Feuverger G., Oasis of Dreams: Teaching and Learning Peace in a Jewish-Palestinian Village in Israel, Routledge, New York 2001.

Forsyth D.R., Group Dynamics, 4th Edition, Thomson Wadsworth, Belmont 2004.

Freeman R.D., Dual Language Planning at Oyster Bilingual School: It's Much More than Language, TESOL Quarterly, 1996, 30(3).

Golan-Agnon D., Why are Arab Students Discriminated Against? [in:] Inequality in Education, Ed. D. Golan-Agnon, Bavel, Tel Aviv 2004 (in Hebrew).

Gollnick D.M., Chinn P.C., Multicultural Education in a Pluralistic Society, Front Cover. D.M. Gollnick, P.C. Chinn, Maxwell Macmillan Canada, Toronto 1994.

Kara H., Research and evaluation for busy practitioners: a time-saving guide, The Policy Press, Bristol 2012.

Lieblich A., Against All Odds: The Story of a Binational Village, Conteno, Tel Aviv 2015.

Neglected Voices and Excessive Demands in Feminist Research, Qualitative Sociology, 1993, $16(1)$.

Peled-Elhanan N., When the Other is Unseen, Unheard, and Unknown: From Teaching as Socialization and Culture to Teaching as Access and Inclusion, Bamikhlala, 2007, 1 (in Hebrew).

Reinharz S., Feminist Distrust: Problems of Content and Context in Sociological Research, [in:] The Self in Social Inquiry, Eds. D. Berg, K. Smith, Sage, Beverly Hills 1985.

Rex J., Singh G., Pluralism and Multiculturalism in Colonial Society - 106 Thematic Introduction, International Journal on Multicultural Societies, 2003, 5, 2.

Rosenwasser N. (Ed.), Group Counseling, Zippori Community Education Center, Jerusalem 1997 (in Hebrew).

Sabar R., Gur Y., Contact Lenses: Intercultural Mediation in a Youth Village with a Large Proportion of Ethiopian Students, Mifgash L'avoda Hinuchit Sotzialit, 2001, 15 (in Hebrew).

Shammai S., Elitub Z., Horowitz T., The Story of an Educational Revolution, Carmel, Jerusalem 2010 (in Hebrew).

Taylor Ch., Multiculturalism and the Politics of Recognition, Ed. A. Gutmann, Princeton University Press, Princeton - New York 1992.

The Ethnography of Peace Education: Some Lessons Learned from Palestinian-Jewish Integrated Education In Israel, [in:] Handbook of Conflict Analysis and Resolution, Eds. S. Byrne, D. Sandole, J. Senehi, I. Staroste-Sandole, Routledge, New York 2008.

Torres-Guzmán M.E., Dual Language Programs: Key Features and Results, Directions in Language and Education, Spring 2002, 14.

Tuckman B.W., Developmental Sequence in Small Groups, Psychological Bulletin, 1965, 63.

Walker A., Priorities, Strategies and Challenges: Proactive Leadership in Multi-Ethnic Schools, National College for School Leadership, 2004, http:/ / citeseerx.ist.psu.edu/viewdoc/ download?doi=10.1.1.520.4816andrep=rep1andtype=pdf [retrieved: 29 April 2017]. 